\title{
Orientation of American Indian Students to Workforce Technology Needs
}

\author{
William Brescia
}

\section{Literature Review}

Higher education and the workplace are becoming more diverse (Probst, 2003), a fact that will have profound effects on both institutions. American Indian students complete fewer undergraduate, master's, or doctoral degrees in comparison to their representation in the general population (Turrentine \& Conley, 2001). This trend has been noted in professions ranging from engineering to student affairs, and attempts have been made to attract qualified minorities to pursue degrees in many subjects, particularly in the areas of science and math (Vidalis \& Najafi, 2003; Archibald, Pidgeon, Janvier, Commodore, $\&$ McCormick, 2002). Most of the research to date has focused on what institutions should do to improve their technology capacity so they can retain minority students once they have started as students in higher education (Dorr \& Akeroyd, 2001).

Throughout higher education, there are efforts to attract and retain American Indian students through programs developed to encourage high performance, create mentor/ protégé relationships, and provide seminars, workshops, and role models (Vidalis \& Najafi, 2003). While many of these programs are designed to support minority students in particular fields of study, overall they strive to do whatever is necessary to keep students at a particular institution.

While some schools have begun to contemplate linkages with tribal workforces, most have not even considered integrating relevant technology education into their curriculum (Wentling \& Waight, 2002). Guidance of American Indian students should focus on where they intend to fit into the tribal workforce. These choices should be based on realistic assessments of what jobs are available, rather than what course work or degrees are offered at a particular college or university.

In an effort to serve American Indian students and their communities well, student services personnel at colleges and universities should consider the needs of both. Just as forward-thinking institutions are offering bilingual orientation programs, those same institutions should provide orientation that supports the workforce goals of American Indian communities (Williams, 2002). American Indian students have strong bonds to their communities, and returning to those communities with needed knowledge and skills remains important to the students as individuals and to tribal enterprises and governments.

Those institutions that have been most successful in retention of American Indian

William Brescia (brescia@uark.edu) is an assistant professor in Educational Technology at the University of Arkansas, Fayetteville. 
students have worked diligently to create and sustain relationships with tribal communities. These programs support early visits to campuses and have well-funded support systems for American Indian students (Brazziel \& Brazziel, 1997). With strong links and mutual respect, tribal communities and institutions of higher education can work together to effectively integrate applicable technology education into every degree program.

There is evidence of the need to effectively prepare American Indian students for workforce roles that include using technology (Anderson, 1999). What are those roles? How can institutions of higher education identify those needs? Only by honoring the will of tribal governments can students be prepared to meet these needs. This paper suggests that one effective way to build effective relationships with Indian communities is to pay attention to workforce technology needs. By establishing what those needs are, college and university staff can provide students with information that will be useful to them in selecting courses and careers and will contribute to lowering attrition rates.

\section{Method}

This study employed the Delphi method, using a multi-stage process of collection and synthesis of data from selected employees from the enterprises and government workforce of a tribe in the United States. This method is designed to systematically collect the judgments of a knowledgeable panel on a particular topic by repeated questioning, interspersed with summarized information and feedback of the group's responses (Delbecq, Van de Ven, \& Gustafson, 1975). The power of this method lies in the use of multiple rounds of inquiry that permit experienced individuals to learn about and build upon the beliefs of other group members. This process can lead to a shared understanding when differences exist and to prioritizing key issues that affect the group.

Participants were tribal employees - tribal members and non-tribal members who possessed knowledge of technology use on the reservation, including technology leaders in the tribal or enterprise workforce with considerable experience in a job that requires technology use or who had significant experience as an administrator of a program or activity that involved technology use (Dalkey \& Helmer, 1963). No demographic descriptors were used in the selection process. Twenty-three employees were identified as possible participants, and 21 agreed to take part in the study.

Open-ended questions were developed to obtain responses that identified participants' current use of technology, how to best prepare students for technology careers, and what advice college and university advising staff should give to students during the orientation process. Participants also suggested additional questions worthy of exploration. Results of the initial round were summarized and resubmitted to the participants as a survey, using a Likert scale to prioritize each response (Murry \& Hammons, 1995).

The emerging priorities were resubmitted and rated again using a 7-point scale. Data was analyzed including the mean $(\bar{X})$, and the range (i.e., the maximum and minimum score each particular item received, an indication of the breadth of difference of opinion) (Hartman, 1981). 


\section{Results}

The primary concern of the respondents was identifying skills that would be valuable to tribal governments and enterprise employees five or more years in the future. When asked what advice tribal members who are college and university students should receive during orientation, responses fell into four main categories: basic skills that every employee should have, the ability to use particular applications that are needed in specific jobs, methods of learning those skills, and critical, high-end skills.

\section{Basic Skills}

From the beginning, the respondents wanted to make one thing clear. The skills of coding and programming were much less important than other skills because only a few employees need those skills. More important skills included: basic computer skills, using presentation software, and using databases. Basic computer skills included learning operating systems and knowing how to make, open, and save files. Other basic skills included being able to use menu, task, and scroll bars; knowing how to manage files; and moving, copying, and deleting files. Due to the importance of sharing information, respondents felt that being able to use presentation software was a skill that everyone should know. In that regard, knowing how to use databases received high mean scores. This included creating, adding to, and searching reports from databases. With tribal governments becoming larger and developing a large variety of entities and functions, linking data will continue to be important to prospective employees.

\section{TABLE 1}

\section{Basic technology skills needed by all employees (7-point scale)}

\begin{tabular}{ll}
\hline Basics & Mean $\bar{X}$ Score
\end{tabular}

$\begin{array}{ll}\text { Database } & 6.28 \\ \text { Presentation } & 6.28 \\ \text { Operating system basics } & 6.22 \\ \text { Comfort with learning how to use technology } & 6.22 \\ \text { Coding and programming } & 4.5\end{array}$

\section{Applications}

The respondents were concerned that students must acquire skills and knowledge for particular jobs or roles in which specific software applications or hardware are used. Employees working in tribal health care must have skills and knowledge in the proper 
use of medical records. Likewise, employees in computing services should know hardware and software well enough to troubleshoot problems and manage local area networks. For tribal governments and enterprises, knowledge of accounting software and tracking of financial records were a necessity for business office staff.

The ability to use communications software applications overlapped many employment areas. The ability to use technology as a communications vehicle and as a tool to relieve some of the burden of paper was a theme that the participants of the study often revisited. Another skill that received a notably high score was the ability to use the various programs in an office suite, including word processing and spreadsheets. Using an Internet browser, especially to research and retrieve important data, was also identified as an important application skill.

TABLE 2

\section{Applications necessary for success in tribal enterprises and govermment (7-point scale)}

\begin{tabular}{lll}
\hline Applications & Mean $\overline{\boldsymbol{X}}$ Score \\
\hline Internet, especially for research & 6.78 \\
E-mail & 6.72 \\
Finance, computer science, medical records & 6.39 \\
Word processing, spreadsheet & 6.39 \\
\hline
\end{tabular}

Learning

Several of the respondents suggested that students at colleges and universities be supplied with computers and special tutoring to make sure they get off to a good start with technology and feel comfortable using technology as a learning tool. The two responses with the highest mean scores were mentoring and internships, which were closely related in methodology. For some time now, planned mentoring programs in higher education have been successful in passing on knowledge and skills in research and teaching. Planned mentoring programs at colleges and universities would be well received by American Indian students. The importance of being flexible in adapting to new learning situations was an important factor leading to success.

The group indicated that to be successful, it would be necessary for students to learn how to use technology in the future. Along with learning how to use technology came the responsibility of using it wisely. Several respondents conveyed the concern that security and sharing data were issues that students should learn about. 


\section{Methods of learning technology skills (7-point scale)}

\begin{tabular}{lll}
\hline Learning & Mean $\overline{\boldsymbol{X}}$ Score \\
\hline Mentoring & 6.389 \\
Internships & 6.28 \\
Learn to be flexible & 6.22 \\
Start early & 6.167 \\
\end{tabular}

\section{High-End Skills}

On the high end, tribal governments and enterprises need a workforce that is highly trained in systems integration and management. Competencies should include the ability to make and put into action decisions on a system-wide basis. The importance of integrating technology into every function in the workplace was emphasized. Tribal employees needed training and support to learn to use technology efficiently and effectively in their jobs. Instructional designers needed to design, develop, and execute instructional programs that address tribal workforce needs.

The respondents supported the idea that becoming a learning institution should be a goal for tribal governments and enterprises. Students should prepare themselves to continue to learn when they enter a tribal workforce because the work environment will be constantly changing, and employees will often need to learn new applications. Respondents identified a willingness to learn as the most important issues. From those learning basic skills to tribal decision makers, members of tribal workforces must be willing to learn to insure success of government and enterprise activities.

\section{TABLE 4}

High-end skills needed by future tribal employees (7-point scale)

\begin{tabular}{lll}
\hline & Desired Skills & Mean $\bar{X}$ Score \\
\hline High End & & \\
& Preparation to learn & 6.556 \\
& Problem solving & 6.06 \\
& Integration of technology into workplace & 6.056 \\
& Systems integration & 6.28 \\
& & \\
\hline
\end{tabular}




\section{Implication for Practice}

In order for American Indian students to successfully complete degrees in higher education, they need to see that they will be learning skills that will be useful for them when they return to their communities. Colleges and universities need to design orientation strategies that insure these students receive guidance which will lead to their retention, followed by successful integration into tribal workforces.

The results show several themes:

1. Orientation should focus on basic computing skills because they are important for the entire tribal workforce. Basic skills included proficiencies in three areas: word processing, databases, and presentation software.

2. Orientation should also focus on the abilities to use an Internet browser for research and to use e-mail to improve performance and communication within the organization, the baseline for all other skills.

3. Students need to know that they should start immediately to overcome any fear of computers while they are pursuing a degree. Students need to learn about and reflect on how to integrate technology into their work life.

4. When students gain employment in tribal workplaces, they should be prepared for an environment that has become a learning institution where everyone is learning new technology skills. Students should be flexible and open to learning new ways to solve problems.

5. College and university staff can support these students by providing them with information that clearly lays out specific career paths which need technology training. Information should also demonstrate how to apply technology knowledge and skills to workforce issues.

\section{References}

Anderson, R. (October 14, 1999). Native Americans and the digital divide. The Digital Beat. 1(17), 1-11.

Archibald, J., Pidgeon, M., Janvier, S., Commodore, H., \& McCormick, R. (2002).

Teacher recruitment, retention, and training: Implications for First Nations education. Paper prepared for Minister's National Working Group on Education Indian and Northern Affairs Canada. Retrieved November 29, 2004, from

http://www.ainc-inac.gc.ca/pr/pub/krw/tec_e.pdf

Brazziel, W. F., \& Brazziel, M. E. (1997). Distinctives of high producers of minority science and engineering doctoral starts. Journal of Science Education and Technology, 6(2), 143-153. Retrieved November 15, 2004, from http://www.kluweronline.com/article.asp?PIPS=424902\&PDF=1

Dalkey, N., \& Helmer, O. (1963). An experimental application of the Delphi method to the use of experts. Management Science, 9, 458-467. 
Delbecq, A., Van de Ven, A. H., \& Gustafson, D. H. (1975). Group techniques for program planning: A guide to nominal group and Delphi processes. Middleton, WI: Green Briar Press.

Dorr, J., \& Akeroyd, R. (2001). Bridging the digital divide. Computers in Libraries, 21(9), 36-42.

Hartman, A. (1981). Reaching consensus using the Delphi technique. Educational Leadership, 38(6), 495-497.

Murry, J. W., \& Hammons, J. O. (1995). Delphi: A versatile methodology for conducting qualitative research. The Review of Higher Education, 18(4), 423-436.

Probst, T. M. (2003). Changing attitudes over time: Assessing the effectiveness of a workplace diversity course. Teaching of Psychology, 30(3), 236-239.

Retrieved December 1, 2004, from http://www.leaonline.com/doi/abs/10.1207\%2FS15328023TOP3003_09

Turrentine, C. G., \& Conely, V. (2001). Two measures of the diversity of the labor pool for entry-level student affairs positions. NASPA Journal, 39(1), 84-102.

Vidalis, S. M., \& Najafi, F. T. (2003). Increasing the diversity in engineering education. Proceedings of the ASEE Southeast Section Conference.

Retrieved December 4, 2004, from http://cee.citadel.edu/aseese/proceedings/ASEE2003/P2003046ADMINEVID.pdf

Wentling, R. M., \& Waight, C. L. (2002). School and workplace initiatives and other factors that assist and support the successful school-to-work transition of minority youth. Journal of Industrial Teacher Education, 37(2). Retrieved December 6, 2004, from http://scholar.lib.vt.edu/ejournals/JITE/v37n2/wentling.html

Williams, T. E. (2002, Spring). Challenges in supporting student learning and success through student services. In T. H. Bers \& H. D. Calhoun (Eds.), Next Steps for the Community College [Special issue]. New Directions for Community Colleges, 117, 67-76. Retrieved December 4, 2004, from

http://sds504001.fa04.fsu.edu/Community_Colleges_Williams.pdf 